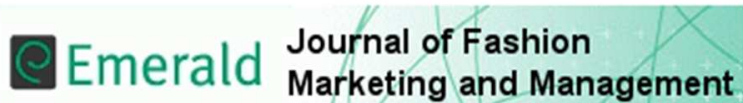

\section{The Relationship Between Design and Marketing in the Fashion Industry}

\begin{tabular}{|r|l|}
\hline Journal: & Journal of Fashion Marketing and Management \\
\hline Manuscript ID & JFMM-04-2016-0041 \\
\hline Manuscript Type: & Editorial (journal staff only) \\
\hline & \\
\hline
\end{tabular}

SCHOLARONE ${ }^{\text {M }}$

Manuscripts 


\section{The Relationship Between Design and Marketing in the Fashion Industry}

This Special Issue investigates key factors in the relationship between designers and marketers in management roles. Several previous studies have investigated the nature of the relationship between marketing and design, viewing them as existing within different cultures and modes of thinking. For example, Roberts-Lombard and Holland (2011) identified key differences in approaches to working practice, in that designers in their study were innovative and creative via design, as well as non-profit-orientated, in contrast to marketers whose creativity was more profit-orientated, driven by the requirements of target customers. Similarly, Beverland and Farrelly (2011) refer to stereotypical views of designers as 'impractical idealists' concentrating on the shape of products and looking to the future, whereas marketers can be perceived as lacking imagination and focusing mainly on how products fit with consumer needs at the present time. As a result of their research, Beverland and Farrelly (2011) proposed that improved relations between marketers and designers via the deployment of 'cultural intelligence' should contribute to improvements in New Product Development (NPD). Similarly Svengren Holm and Johansson (2005) identified differences in the mindsets of designers and marketers and identified five key factors of co-operation between the two specialisms: 1) attitude towards the product 2) professional identity 3) attitudes towards corporate identity 4) relation to value creation and 5) approach to consumer and market research. Other researchers have proposed practical solutions to integrate design and marketing effectively, e.g. by locating these departments in close proximity and conducting cross-functional reviews (Leenders and Wierenga, 2002). However, previous research in this field has concentrated largely on product design, rather than fashion, with limited reference to design in relation to other aspects of the marketing mix, hence the requirement for a journal issue on this topic.

An emerging interest in creativity and creative organisations during the 1990s turned managers towards design and its contribution to business innovation. Design thinking offered ways to develop new concepts, methodology and practices in products, services and experiences. These were evident in complex, 'wicked' problem-solving capabilities, abductive approaches and design tool-kits. Distinctive designs were seen to provide marginenhancing solutions to commodification and cost-driven marketing mixes. Consequently the two disciplines of design and marketing closed in on similar fields of research at times integrating but also competing, notably in branding where design and marketing-led approaches offer similar contributions to management practice and academic research. Broadly, designers and marketers have the same aims to maintain or improve the performance of the organisation in which they are employed. However, their objectives towards achieving this aim can differ and lead to potential organisational dissonance. In this context the first workshops were hosted by Professor Tony Kent, Professor T.C. Melewar and Professor Charles Dennis at the University of the Arts and Brunel University. Subsequently the International Colloquium on Design, Branding and Marketing was conceived by the founders, who launched their first colloquium in 2011, with the aim of developing new insights and knowledge of points of difference and convergence.

This Special Issue largely derives from the second colloquium in 2014, which offered a focus for design and marketing, with a strong contribution from fashion marketing academics. These disciplines are particularly interesting to researchers in consumption, identity and branding, and in recent years, luxury, as evidenced by the current popularity of articles on luxury fashion in JFMM. Moreover the fast fashion system provides further research challenges in the complexity of its supply chains and markets, dynamics and global reach. Fashion has a fundamental relationship with design. It distinguishes the designer, the label and the brand with a consistent and recognisable identity. Branding has become an essential component of marketing, in attracting and retaining customers and brand equity is a major concern in valuing fashion businesses (Johansson and Svengren Holm, 2004), intersecting between the design and marketing functions. 
The relationship between design, marketing and branding is increasingly complex in the interweaving of products, services and experiences. Design has become progressively more significant in business-to-consumer markets in recent years, with increasingly design-led products, retail environments and promotion now being the norm, in differentiating retailers from their competitors in a volatile financial climate. Meroni and Sangiorgi (2011) distinguish $21^{\text {st }}$ century design from the previous century by its complexity and movement away from the design of simple objects. The designing process and outcomes now hinge on unpredictable factors, characterised by a social economy with a variety of actors and motivations and the dynamics of social innovation. The designing process concerns entities in the making, whose final characteristics will emerge only in the complex dynamics of the real world. In one sense, design as 'embracing any innovative activity' is a generic approach, where "everyone designs who devises courses of action aimed at changing existing situations into preferred ones" according to Simon (1996:236). Design therefore encompasses all creative professions that modify their environment.

Design is a crucial component of fashion businesses, since it enables consumers to select and construct their own identities and in conjunction with marketing, has a pivotal function in shaping consumption. Design thinking is now seen as an enabler helping to unlock latent creativity, developing solutions to problems and shaping the future (Cooper, 2012). A design mind-set does not worry about constraints: it always sees ways round them (Martin, 2009). In so doing, the designer has moved from a lone problem solver, engaged in the processes and outputs of design, to a facilitator and navigator of interdisciplinary teams. Marketers can benefit from design-thinking when approaching creative tasks and equally, designers can gain valuable insights from marketers' consumer-orientated approach to business, largely via market research into customers and competitors.

The literature indicates that organisations have generally moved away from a production orientation towards a more market-orientated approach, where customer needs predominate and production issues have become secondary. Lusch and Vargo (2006) have taken this a step further by introducing their service-dominant logic (S-D Logic) concept, proposing that organisations of all types are primarily service-based. However, whilst S-D Logic has proven to be a popular concept in the marketing field, it could have the potential to create tension between designers and marketers, since it steers design away from its existing focus on products to one of engagement, participation and co-creation.

\section{The location of design and marketing in the fashion industry}

The designer, the fashion label and brand are influenced, albeit in varying degrees, by their location: the places where designers work, present their collections and communicate through the media (Kent 2016). Within the organisation several key issues have emerged. Firstly and most importantly, there is a direct link between design and marketing management in this industry; clearly design can be central to key roles in the organisation. In some cases this leads to a profoundly 'hands on' approach. Secondly, access to the most senior levels of design management in fashion retailers is contingent upon formal design training and extensive experience (Miller and Moultrie, 2011). Within fashion companies, design and marketing functions are often located separately, depending on the scale of the company thus placing unnecessary restraints on opportunities for interaction between these two creative fields.

Outside the organisation, the place of design in fashion has become more nuanced. Fast fashion enables consumers to create their own identity and multiple identities. Its eclecticism provides access to new ideas and products, and focuses on availability and affordability. 
Consequently design is driven by speed and accuracy of interpretation for specific consumer markets, and originality can be defined by interpretation and personalisation. Indeed multiple media enable fashion to be disseminated so quickly and with so many interpretations that looks and styles follow fast on each: designer collection is replaced by consumer 'mash up'. This level of co-creation forms an important element in the papers presented in this edition.

Organisational responses to changes in consumption and consumer identity and the ascendancy of services and experiences, have, in part been realised by customisation. As Skov (2002) demonstrates, the emergence of mass customised designer labels in the 1990s would have been difficult to achieve without access to global manufacturing networks. Such changes allow fashion designers the means to respond to new ideas and creative directions, while fuelling the dynamics of fast fashion and the micromarket of the individual. The speed of change means that effective and rapid communication between designers and marketers has become increasingly significant, facilitated by the development of more sophisticated methods of interacting digitally. The rapid development of online connectivity, versatility, and computing power has generally extended the opportunities for personalisation to meet customers' very specific needs at their request, thus addressing both design and marketing issues simultaneously, whilst making consumers central to the process.

\section{Addressing sustainability in the fashion business}

Consumers, brands and retailers have reacted to the prevalence of fast fashion, evident in the emergence of more sustainable ranges of clothing. After a stalled start in the 1990s, sustainability has gained more of a foothold in recent years, to the extent that it has been trialled by many mainstream retailers. This is another example of an area where the relationship between designers and marketers is important, since sustainable design requires information on the requirements of consumers that can be provided by the marketing function.

An alternative view of fashion design sees consumers as users, in which the designer takes a different, more market-orientated role. Co-design defines this collective creativity across the whole span of a design process. Broadly it refers to the creativity of designers and people not trained in design working. Slow fashion has embraced small-scale production, traditional craft techniques, local materials and markets, which challenge growth fashion's obsession with mass-production and globalised style. It emphasises making and maintaining actual material garments, and re-finding earlier experiences of fashion linked to active making rather than watching (Fletcher, 2010). The slow approach presents some alternative ways of addressing issues of fashion design and sustainability at a relatively local level by activating the potential for personal connection to garments to increase their longevity. It offers collaborations that challenge existing hierarchies of 'designer', 'producer', 'marketer' and 'consumer'. The development of more sustainable fashion products facilitates collaboration between designers and marketers on common ground, where they can jointly learn about and respond to the emergence of sustainability issues.

\section{Industry perspectives on the relationship between design and marketing}

To provide a fully rounded perspective on the topic of this Special Issue, the two keynote speakers from ICDBM 2104 were invited to offer their views on the relationship between design and marketing, based on their own experiences in industry. Fiona Lambert, former Vice-President of George Clothing, and Brand Design Business Development Consultant Martin Knox, were asked firstly for their opinions on the advantages of collaboration between marketers and designers. Both of our speakers advocated close interaction between these two key business functions. Fiona stated: 
Ultimately the end goal of a designer is to sell their product to the consumer. The close relationship and understanding between the marketer and the designer means that the designer's vision and DNA can be translated into a campaign that represents what they have created and can be put to the customer in a desirable way.

Martin also considered collaboration to be essential for designers and marketers:

Increasingly, collaborations are happening with unusual disciplines coming together to solve new problems. When people collaborate things get done, siloes are broken down and you can develop a common language and understanding of how each other's discipline works. Other advantages are solving problems and facing challenges jointly. The role of the marketer and the role of the designer are becoming increasingly nebulous; the traditional designer and marketer are dying out. People who are creative and open are able to work with people from other disciplines. Titles are anachronistic, they're meaningless now, they come from a bygone age. I'd give them a course title and have a definition of what you mean by that, its purpose, provenance and practicalities. Marketing is so nebulous a term it's so difficult for a marketer to economically justify what they do; they don't make anything and cannot possibly guarantee any particular outcome. They're working in the future so they need to be prepared to make themselves aware of everything that's going to impact their future. The product is going to take six months to a year to bring to market and things are going to change massively in that time. Marketing departments are increasingly becoming operational and reactive. I think marketing is taught as a science and it's been turned into something that's a rational, ordered process.

However, in Martin's experience in industry, designers and marketers frequently did not work together effectively and he questioned whether students were taught enough about relationships between disciplines to prepare them for the 'real world', due to the relatively narrow focus of their studies:

There's a mutual disrespect and mutual lack of understanding. For collaborations to work there has to be at least mutual respect and making a bit of space for mutual understanding and identifying synergies, because often a marketer is a frustrated designer.

When asked for her views on specific problems between design and marketing, Fiona replied:

Communication and being able to paint a picture of what you want the customer to see about your design/brand and why it's important. In launching the new George Home range in 2014, I was successful in generating an understanding that the driver to purchase Home products start with design, colour co-ordination, print and textiles and the marketing plan focussed on these. The pricing was put on pack versus on shelf to generate a trust in the price and taken to a low-key black and white, smaller font together with beautiful photography creating true value. Having worked in the Supermarket sector of Clothing and Home, there is a challenging dynamic where marketing's main focus is food, where price is key and clothing where value is key. It can lead to the wrong representation of what are the key selling points of what has been created.

To encourage designers and marketers to work together effectively in practice, Martin recommends that the two functions should be open with each other and willing to share their knowledge, showing each other the processes they go through, in order to build mutual understanding:

Marketing is about system and process, design is about ideas but there's system and process involved in creating a design and there are ideas and creativity involved in the marketing process. The two disciplines have been about stages in a process, so someone makes a product, gives it to a marketer, the marketer strategises and the 
designer designs the product and the packaging for it to go in. Each stage is separate, but this doesn't work anymore. The root cause is ownership, so the designers want ownership of what they do and the marketers want ownership of what they do... but the new economy that's emerging is about collaboration and creative commons and sustainability. The designer must consider far more than the aesthetics. It is critical for a designer to fully understand the discipline that he or she works in, that includes how to conceive as well as how to make and realise something. There's a massive shortage of technical skills in the UK and the Universities are perfectly positioned to set up centres of manufacture or prototyping. The educators have a big responsibility. It's their job to get people out into the world with the skillsets to be able to deal with the challenges that they're going to face. I'll throw open a challenge to come up with relevant and pertinent definitions of design, marketing and sustainability.

Interest in the emerging field of collaboration between design and marketing is evidenced by the issues raised in this introductory article and the growing attendance rate at ICDBM. The various topics discussed here demonstrate the scope for positive collaboration between designers and marketers in the context of the contemporary fashion industry, many elements of which were explored at the 2014 colloquium, from which an edited selection of papers features in this Special Issue.

Bethan Alexander's article considers the motivations of luxury fashion brands to enter into inter-industry creative collaborations, as well as the attitudes of consumers towards such collaborations and the consumer-based brand equity effects thereof. The luxury fashion sector encompasses some of the world's most influential brands and is characterised by a high level of creativity as well as powerful marketing. This study explores four types of collaboration, involving composite branding, dual branding, ingredient branding and experiential marketing. Adopting a multiple case study approach with primary data collected from industry and consumer sources, the outcome of the study is a conceptual framework connecting the motivations, elements and effects of inter-industry creative collaborations in luxury fashion. The study highlights the importance of close alignment between design and marketing functions for success in the dynamic luxury fashion sector.

Karla Straker's article addresses the intersection between design and marketing in the context of digital channels, by exploring how consumer emotions are evoked through digital channel experiences. The study adopted a single revelatory case approach and analyses the customer experience of five Burberry digital campaigns from 2009-2014. The outcome of the study is a conceptualisation of the digital engagement emotion loop, based on Damasio's (1994) Somatic Feedback Theory, outlining the process of how consumers process and respond to brand stimuli, which then informs their attitude or behaviour towards the brand. Since consumer emotions affect attitude and behaviour towards brands, appropriate design of engaging digital channel experiences is critical for forming successful brand-consumer relationships and retaining consumers.

Ana Roncha and Natascha Radclyffe-Thomas's article considers the use of social media platform Instagram in co-creating value between a fashion brand and its consumers. The study adopts a qualitative single case study approach, with data collected from industry and consumer sources, to explore TOMS' 2015 marketing communication campaign \#withoutshoes. Data were analysed against the five processes of sharing, co-developing, socialising, advocating and learning in Brodie et al's (2013) framework of online engagement. The authors conclude that design of brand-consumers interactions should incorporate specific tasks, platforms, tools and mediums. Leveraging the power of social media facilitates the ability of consumers to co-create value with the brand, which raises the effectiveness of the marketing communication campaign and supports relationship building. 
Jennifer Millspaugh and Tony Kent's article takes a broader view of co-creation in the marketplace and considers the influence of not only consumers, but also the wider fashion system in the international development process of entrepreneurial designer fashion brands. Adopting a qualitative grounded theory approach, primary data were collected from designer fashion enterprises and the wider community of industry stakeholders. Data analysis revealed that brand identity is developed over time through the interactive process of presenting ideas, interpreting experiences and reacting to learning. Whilst brand identity may be initially born out of the aesthetic innovation of the designer's collections, the ongoing development of brand identity is guided by interactions with stakeholders in the fashion system, representing a combination of design and marketing-led forces.

Mirsini Trigoni's study explores the use of visual elements in magazines to differentiate a brand, increase brand loyalty and target different market segments. The study adopts a visual research methodology to explore the design features of three home interior magazines from 1997-2006, according to Rose's (2001) key components of content, colour, spatial organisation and light. Data analysis of image features suggests that design and marketing techniques are manipulated according to target market segment and can strengthen the relationship between the reader and the magazine, thus enhancing brand loyalty. Visual research methodologies may also be used to analyse fashion imagery in the context of editorial, advertising, brand websites and social media platforms.

The guest editors would like to thank the Editor-in-Chief for the Journal of Fashion Marketing and Management, Steven George Hayes, for his assistance with the organisation of this special issue. They also extend their thanks to all contributors and anonymous reviewers for their valuable contributions, as well as participants at ICDBM 2014 and the ICDBM workshop in 2015, whose feedback helped to shape these papers.

Further updates on ICDBM events are available on Twitter@ICDBM2016.

\section{References}

Beverland, M.B. and Farrelly, F.J. (2011), "Designers and marketers: Towards a shared understanding", Design Management Review, Vol.22, No.3, pp. 62-70.

Brodie, R.J., Ilic, A., Juric, B. and Hooebeek, L. (2013),"Consumer engagement in a virtual brand community: An exploratory analysis", Journal of Business Research, Vol. 66, pp. 105114.

Cooper, R. D. (2012), "Design leadership in a vortex of change'. Design Management Journal, Vol. 7, No.4, pp. 3-5.

Damasio, A. (1994), Descartes' Error: Emotion, Reason, and the Human Brain. New York: Putnam.

Fletcher, K. (2010), "Slow fashion: An invitation for systems change", Fashion Practice, Vol. 2, No. 2, pp. 259-266.

Johansson, U. and Svengren Holm, L. (2004), "The Relationship between the Discourses of Brand Management and Design Management”. Working paper. Stockholm: Stockholm University School of Business. 13th May.

Kent A.M. (2016), "Personalisation in fashion design" in T. Fisher and I. Kuksa (eds.) Design for Personalisation, Aldershot: Gower.

Leenders, M.A. and Wierenga, B. (2002), "The effectiveness of different mechanisms for integrating marketing and R\&D”, Journal of Product Innovation Management, Vol. 19, No.4), pp. 305-17.

Lusch, R.F. and Vargo, S.L. (Eds.) (2006), The Service-Dominant Logic of Marketing:

Dialog, Debate and Directions, Armonk, NY: M.E. Sharpe.

Martin, R. (2009), The Design of Business. Boston MA: Harvard Business School Publishing. Meroni, A. and Sangiorgi, D. (2011), Design for Services. London: Gower. 
Miller, K. and Moultrie, J., (2011), “Old industry, new thinking : towards a model of design management in the fashion retail industry". In the Proceedings of the Cambridge Academic Design Management conference. Cambridge: University of Cambridge.

Roberts-Lombard, M. and Holland, R. (2011), "Is there a case to be made for the integration of design and marketing?", First Global Design, Branding and Marketing Colloquium, University of Lincoln, December 2011.

Rose, G. (2012), Visual Methodologies: An Introduction to Researching with Visual Materials. London: Sage Publications.

Simon, H. (1996), The Sciences of the Artificial, Cambridge, MA: MIT Press.

Skov, L. (2002), "Hong Kong fashion designers as cultural intermediaries: Out of global garment production", Cultural Studies, Vol.16, No.4, pp. 553-569.

Svengren Holm, L. and Johansson, U. (2005), "Marketing and design: Rivals or partners?", Design Management Review, Vol.16, No.2, pp.36-41. 